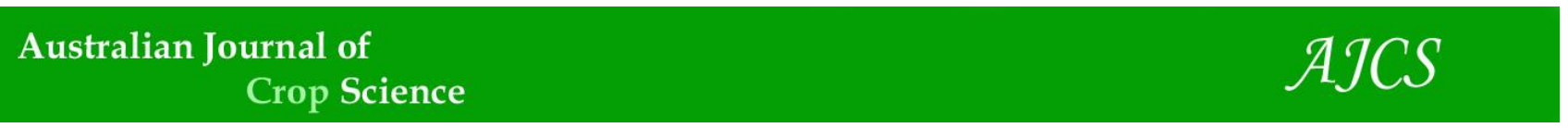

AJCS 15(04):479-483 (2021)

ISSN:1835-2707

doi: 10.21475/ajcs.21.15.04.p2335

\title{
Physiological quality of pitaya seeds subjected to different methods of mucilage extraction
}

\author{
Alessandro Borini Lone ${ }^{1}$, Viviane Yumi Baba², Thiago Alberto Ortiz ${ }^{3 *}$, Lucia Sadayo Assari \\ Takahashi $^{4}$
}

${ }^{1}$ Santa Catarina State Agricultural Research and Rural Extension Agency (EPAGRI), 6800, 88318-112, ItajaíSC, Brazil

${ }^{2}$ State University of Londrina (UEL), 6001, 86051-990, Londrina-PR, Brazil

${ }^{3}$ Iporã Faculty (FIP), 640, 87560-000, Iporã-PR, Brazil

${ }^{4}$ State University of Londrina (UEL), 6001, 86051-990, Londrina-PR, Brazil

${ }^{*}$ Corresponding author: thiago.ortiz@hotmail.com

\begin{abstract}
The selection of seed extraction methods from flesh fruits depends on the characteristics of the fruit and the seed to ensure their physiological quality, viability, vigor and sanity within the acceptable percentage for each species. The present study aimed to assess the physiological quality of pitaya seeds subjected to different extraction methods of the mucilage surrounding the seeds. The assessed methods were $M_{1}$ - friction in sieve under running water; $M_{2}$ - friction in sieve under running water, with addition of $\mathrm{CaO} ; \mathrm{M}_{3}-$ fermentation for $24 \mathrm{~h} ; \mathrm{M}_{4}-$ fermentation for $24 \mathrm{~h}$, with addition of sucrose; $\mathrm{M}_{5}-$ fermentation for $48 \mathrm{~h}$; $\mathrm{M}_{6}-$ fermentation for $48 \mathrm{~h}$, with addition of sucrose; $\mathrm{M}_{7}-$ immersion for $2 \mathrm{~h}$ in $2.5 \% \mathrm{HCl}$ solution; $\mathrm{M}_{8}-$ immersion for $2 \mathrm{~h}$ in $5.0 \% \mathrm{HCl}$ solution and $\mathrm{M}_{9}$ - immersion for $2 \mathrm{~h}$ in $10.0 \% \mathrm{HCl}$ solution. The experimental design was entirely randomized. The analyzed variables were germination percentage (\%), germination speed index (GSI) and mean germination time (MGT - days), as well as identification and quantification (\%) of plant pathogenic fungi based on germination and accelerated aging tests; percentage of viable seeds (\%) based on tetrazolium test; and vigor $\left(\mu \mathrm{S} \mathrm{cm}^{-1}\right)$ based on electrical conductivity test. The method of immersion for 2 $\mathrm{h}$ in $10.0 \% \mathrm{HCl}$ solution $\left(\mathrm{M}_{9}\right)$ has proven to be advantageous for the extraction of $\mathrm{H}$. undatus seeds to favor seeds with higher physiological quality in a short period.
\end{abstract}

Keywords: Accelerated aging; Electrical conductivity; Germination; Hylocereus undatus; Tetrazolium; Vigor.

Abbreviations: Asp_Aspergillus sp.; Pen_Penicillium sp.; Rhi_Rhizopus sp.; Cur_Curvularia sp.; Cla_Cladosporium sp.; Colle_Colletotrichum sp.

Introduction

Pitaya is the name given to the fruits of several climbing cacti, containing small digestible seeds and a pericarp that may or may not have spines, despite their easy removal during maturation (Nerd et al., 2002). Some species have found to be suitable for cultivation and commercialization (Le Bellec et al., 2006), with emphasis to Hylocereus undatus (Haworth) Britton \& Rose, the most cultivated in the world (Nerd et al., 2002).

Its characteristics are oblong fruit, with a red pericarp and white pulp, small and numerous seeds ( $3 \mathrm{~mm}$ long) of dark color (shiny black), distributed throughout the pulp, with a surrounding mucilage (sarcotesta) (Canto, 1993; Mizrahi et al., 1997; Anderson, 2001).

The reproduction of pitaya can be asexual (vegetative) or sexual (through seeds). Plant propagation by seed is convenient, particularly in breeding programs, where materials with desirable genetic information are obtained, and the characteristics can be used in the selection of genotypes (Andrade et al., 2008).
The selection of seed extraction methods from flesh fruits depends on the characteristics of the fruit, the seed attachment to the fruit, the presence of sarcotesta, the development of pathogens transmitted by the seed, and the fruit volume (Carvalho and Nakagawa, 2012). According to these authors, manual pulping avoids mechanical damage, ensuring the physiological quality of the seeds.

Sarcotesta is a gelatinous material that involves the seeds of some plant species, which may cause germination to become slow and uneven, resulting in heterogeneous seedling development. It can also serve as a substrate for the development of microorganisms that may impair the quality of seeds, interfering with the germination process (Marin et al., 1987).

Among the methods used to remove the sarcotesta, Carvalho and Nakagawa (2012) reported mechanical removal with mixer at low speed or manual smear, fermentation, and the use of acids and bases. Sousa et al. (2009) noticed that fermentation (distilled water and sucrose) was effective in eliminating seeds sarcotesta of 
Opuntia ficus-indica (cactaceae). Cavariani et al. (1994), in turn, did not observe any difference in the germination of tomato seeds (Lycopersicon esculentum) subjected to mucilage removal by fermentation $(72 \mathrm{~h})$ and with hydrochloric acid $(\mathrm{HCl}$ at $2.5 \%)$.

The choice of the method for seeds removal of flesh fruit and of the mucilaginous layer covering the seeds should consider the species involved to avoid harming seed viability and vigor. Due to the lack of scientific data on extraction methods of $H$. undatus seeds to ensure viability, vigor and sanity of the seeds, the present study aimed to assess the physiological quality of $H$. undatus seeds subjected to different extraction methods of the mucilage surrounding the seeds.

\section{Results and Discussion}

\section{Viability, vigor and sanity of pitaya seeds subjected to} different methods of mucilage extraction

The germination percentage of Hylocereus undatus seeds obtained from germination and accelerated aging tests showed no statistically significant difference using the extraction methods investigated (Table 1). Similarly, Cavariani et al. (1994) did not find statistically significant differences in the germination of seeds of Lycopersicon esculentum Mill.; in the assessment of the following extraction methods (washing in running water, fermentation for $72 \mathrm{~h}$, immersion for $2 \mathrm{~h}$ in $2.5 \% \mathrm{HCl}$ solution, immersion in $10.0 \%$ commercial acetic acid solution, and immersion for 2 hours in $2.5 \%$ ammonium hydroxide solution).

Martins et al. (2006), in the assessment of different methods of aryl removal from Passiflora edulis Sims f. flavicarpa Deg., also did not obtain any statistically significant difference in germination between the following methods: immersion for $10 \mathrm{~min}$ in $10 \% \mathrm{CaO}$ solution, natural fermentation for $144 \mathrm{~h}$, and friction in stainless steel mesh sieve with and without coarse sand for $3 \mathrm{~min}$ followed by washing in running water. However, Bisognin et al. (1997) obtained seeds of Lagenaria siceraria (Mol.) Standl with higher physiological quality when they were extracted by water fermentation compared to the control treatment and immersion in $\mathrm{HCL}$ solution.

Assessing the influence of methods for aryl removal on the physiological quality of seeds of Passiflora alata Curtis, Osipi et al. (2011) observed that the manual method of aryl removal with friction in stainless steel mesh sieve followed by washing in running water until total cleaning of the mucilage provided favorable results to seed germination, with lower percentage of non-germinated seeds. In the present study, the applied method also enabled a high germination percentage. However, the referred methodology did not provide statistically significant differences in comparison to other methods applied to seeds obtained from germination and accelerated aging tests.

Analysis of the variable GSI showed that for germination test, extraction methods $M_{2}, M_{5}, M_{6}, M_{7}, M_{8}$, and $M_{9}$ favored the vigor of these seeds species, unlike the other methods characterized by slower germination. This was not observed in the analysis of variable GSI in seeds obtained from accelerated aging test, since there were no significant differences between the methods (Table 1).

Alves et al. (2009) reported that fermentation was efficient to remove aryl in seeds of Talisia esculenta (St. Hil) Radlk, observing an increase in the germination percentage and GSI, according to the time of fermentation. Similarly, Lopes et al. (2001) reported that fermentation was effective in the elimination of sarcotesta, due to the advantageous effect of fermentation, up to $72 \mathrm{~h}$, on the physiological quality of Punica granatum L. seeds, with increase in the germination percentage and in germination speed index.

Regarding the variable MGT from germination test, the methods $M_{2}, M_{4}, M_{5}, M_{6}, M_{7}, M_{8}$, and $M_{9}$ demanded less time to germinate, differing from $M_{1}$ and $M_{3}$; and these, in turn, differ from each other. Again, method $M_{1}$ provided seeds with lower physiological quality, because of this later germination characterized by the greater number of days needed for germination (Table 1). In turn, Bisognin et al. (1997) reported increase in the variable MGT in seeds of $L$. siceraria when extraction was done by immersion in solution containing increasing concentrations of $\mathrm{HCl}(10,20,30 \%)$. This decrease in vigor differs from the observed in the present study, and can be related to the difference in the concentration of acid used, since the referred authors used higher concentrations.

Concerning the accelerated aging test, the MGT of methods $M_{4}, M_{5}$, and $M_{9}$ again demanded less time to germinate, differing from the other treatments (Table 1). The pulping methods with later germinations were probably not able to effectively remove the mucilage surrounding the seeds, thus causing delay in the germination. In this regard, according to Taylorson and Hendricks (1977), the phenolic compounds on the mucilage retain oxygen, which could limit its supply to the embryo during germination, causing dormancy, and according to Marin et al. (1987), the gelatinous cover may turn germination slow and uneven.

Seed contamination by plant pathogenic fungi was low during the standard germination test, and the main fungal species were Cladosporium sp., Rhizopus sp., Aspergillus sp. and Penicillium sp.. The methods that did not show fungal contamination were $M_{1}$ and $M_{6}$. On the other hand, the extraction methods with higher means of fungal contamination were methods $M_{4}$ and $M_{5}$ (Table 2). However, it should be stressed that low contamination by plant pathogenic fungi (values lower than $0.7 \%$ ) were obtained with all the assessed methods from seeds obtained by germination test. This confirms that none of the methods assessed favors contamination by the referred microorganisms.

Regarding the residual seeds of the accelerated aging test, there was an increase in the percentage of contamination compared to those of the germination test, especially from microorganisms Aspergillus sp. and Penicillium sp., which occurred, in average, from 2.61 and $3.00 \%$, respectively, in the experimental units of the extraction methods assessed. However, there was decreased contamination by Rhizopus sp. $(0.06 \%)$ and no contamination by the other fungi (Cladosporium sp., Curvularia sp. and Colletotrichum sp.) (Table 2). Regarding the assessed extraction methodologies, there was an increase in fungal growth in all the cases, except for method $M_{3}$, in the seeds obtained with the accelerated aging test compared to those obtained using the germination test. Still, none of the methods significantly favored contamination by plant pathogenic fungi in seeds obtained from accelerated aging test.

Regarding the tetrazolium test, it was found that the percentage of viable seeds, ranging from 84 to $95 \%$ (unreported data), was not significant for any of the extraction methods used, confirming that the viability of the seeds was not influenced by the assessed methods. 
Table 1. Germination percentage (\%G), germination speed index (GSI) mean germination time (MGT - days), from the germination and accelerated aging tests, of pitaya seeds (Hylocereus undatus) under different methods extraction.

\begin{tabular}{|c|c|c|c|c|c|c|}
\hline \multirow{2}{*}{$\begin{array}{l}\text { Extraction } \\
\text { methods* }\end{array}$} & \multicolumn{3}{|c|}{ Germination } & \multicolumn{3}{|c|}{ Accelerated aging } \\
\hline & $\% G$ & GSI & MGT & $\% \mathrm{G}$ & GSI & MGT \\
\hline $\mathrm{M}_{1}$ & $97 a$ & $9.62 \mathrm{~b}$ & $5.22 \mathrm{a}$ & $92 \mathrm{a}$ & $12.15 \mathrm{a}$ & $3.97 \mathrm{a}$ \\
\hline $\mathrm{M}_{2}$ & $95 \mathrm{a}$ & $11.53 \mathrm{a}$ & $4.34 \mathrm{c}$ & $93 \mathrm{a}$ & $11.66 \mathrm{a}$ & $4.15 \mathrm{a}$ \\
\hline$M_{3}$ & 95 a & $10.33 b$ & $4.83 b$ & $97 a$ & $12.62 \mathrm{a}$ & $3.96 \mathrm{a}$ \\
\hline $\mathrm{M}_{4}$ & $86 a$ & $9.84 \mathrm{~b}$ & $4.62 \mathrm{c}$ & $92 \mathrm{a}$ & $12.82 \mathrm{a}$ & $3.74 b$ \\
\hline $\mathrm{M}_{5}$ & $95 \mathrm{a}$ & $11.32 \mathrm{a}$ & $4.34 \mathrm{c}$ & $94 a$ & $13.18 \mathrm{a}$ & $3.72 \mathrm{~b}$ \\
\hline $\mathrm{M}_{6}$ & $94 \mathrm{a}$ & 10.85 a & $4.49 c$ & $95 \mathrm{a}$ & $12.26 \mathrm{a}$ & $4.04 \mathrm{a}$ \\
\hline$M_{7}$ & $97 a$ & $12.02 \mathrm{a}$ & $4.28 c$ & $96 \mathrm{a}$ & $12.51 \mathrm{a}$ & $3.94 \mathrm{a}$ \\
\hline $\mathrm{M}_{8}$ & $98 \mathrm{a}$ & 11.90 a & $4.22 c$ & $98 \mathrm{a}$ & $12.48 \mathrm{a}$ & $4.12 \mathrm{a}$ \\
\hline $\mathrm{M}_{9}$ & $92 \mathrm{a}$ & $11.45 \mathrm{a}$ & $4.23 \mathrm{c}$ & $96 \mathrm{a}$ & $12.91 \mathrm{a}$ & $3.89 \mathrm{~b}$ \\
\hline CV (\%) & 6.90 & 5.66 & 4.83 & 8.00 & 5.70 & 4.25 \\
\hline
\end{tabular}

Table 2. Occurrence (\%) of plant pathogenic fungi in pitaya seeds (Hylocereus undatus) submitted to different seed extraction methods in the standart germination test and germination test after accelerated aging.

\begin{tabular}{|c|c|c|c|c|c|c|c|}
\hline \multirow{2}{*}{ Extraction methods } & \multicolumn{6}{|c|}{ Germination } & \multirow{2}{*}{ Mean } \\
\hline & Asp. $^{*}$ & Pen. & Rhi. & Cur. & Cla. & Colle. & \\
\hline$M_{1}$ & 0.00 & 0.00 & 0.00 & 0.00 & 0.00 & 0.00 & 0.00 \\
\hline $\mathrm{M}_{2}$ & 0.00 & 0.00 & 0.00 & 0.00 & 1.50 & 0.00 & 0.25 \\
\hline$M_{3}$ & 0.00 & 0.00 & 0.00 & 0.00 & 1.50 & 0.00 & 0.25 \\
\hline $\mathrm{M}_{4}$ & 0.50 & 0.50 & 2.50 & 0.00 & 0.00 & 0.50 & 0.67 \\
\hline $\mathrm{M}_{5}$ & 1.00 & 1.50 & 1.50 & 0.00 & 0.00 & 0.00 & 0.67 \\
\hline$M_{6}$ & 0.00 & 0.00 & 0.00 & 0.00 & 0.00 & 0.00 & 0.00 \\
\hline$M_{7}$ & 0.00 & 0.00 & 0.00 & 0.50 & 0.00 & 0.00 & 0.08 \\
\hline$M_{8}$ & 0.50 & 0.00 & 0.00 & 0.00 & 0.00 & 0.00 & 0.08 \\
\hline $\mathrm{M}_{9}$ & 0.00 & 0.00 & 0.00 & 0.00 & 1.50 & 0.00 & 0.25 \\
\hline Mean & 0.22 & 0.22 & 0.44 & 0.06 & 0.50 & 0.06 & \\
\hline \multirow{2}{*}{ Extraction methods } & \multicolumn{6}{|c|}{ Accelerated aging } & \multirow{2}{*}{ Mean } \\
\hline & Asp. $^{*}$ & Pen. & Rhi. & Cur. & Cla. & Colle. & \\
\hline $\mathrm{M}_{1}$ & 5.00 & 4.50 & 0.00 & 0.00 & 0.00 & 0.00 & 1.58 \\
\hline $\mathrm{M}_{2}$ & 4.00 & 7.00 & 0.00 & 0.00 & 0.00 & 0.00 & 1.83 \\
\hline$M_{3}$ & 0.00 & 1.00 & 0.00 & 0.00 & 0.00 & 0.00 & 0.17 \\
\hline $\mathrm{M}_{4}$ & 4.00 & 5.50 & 0.50 & 0.00 & 0.00 & 0.00 & 1.67 \\
\hline $\mathrm{M}_{5}$ & 4.00 & 1.50 & 0.00 & 0.00 & 0.00 & 0.00 & 0.92 \\
\hline$M_{6}$ & 0.00 & 4.50 & 0.00 & 0.00 & 0.00 & 0.00 & 0.75 \\
\hline$M_{7}$ & 2.50 & 2.50 & 0.00 & 0.00 & 0.00 & 0.00 & 0.83 \\
\hline$M_{8}$ & 0.50 & 0.50 & 0.00 & 0.00 & 0.00 & 0.00 & 0.17 \\
\hline $\mathrm{M}_{9}$ & 3.50 & 0.00 & 0.00 & 0.00 & 0.00 & 0.00 & 0.58 \\
\hline Mean & 2.61 & 3.00 & 0.06 & 0.00 & 0.00 & 0.00 & \\
\hline
\end{tabular}

${ }^{*}$ Pathogenic fungi in pitaya seeds: Asp. = Aspergillus sp., Pen. = Penicillium sp., Rhi. $=$ Rhizopus sp., Cur. $=$ Curvularia sp., Cla. $=$ Cladosporium sp., Colle. $=$ Colletotrichum sp..

Regarding the electrical conductivity test (for $24 \mathrm{~h}$ and $48 \mathrm{~h}$ ) values equal to zero were obtained for all the extraction methods assessed (non-tabulated data); thus, it is confirmed that no treatment caused damage to the cells of the seeds and were satisfactory in this regard. It is known that vigor is directly related to the integrity of the cellular membranes of the seeds (Marcos Filho, 2005); also, with the process of deterioration, there is leaching of the cellular components of the seeds soaked in water due to the loss of integrity of the cellular systems. Thus, low conductivity means high quality of seed; high conductivity or higher leachate output, in turn, indicates low quality of the seed.

However, Cavariani et al. (1994) assessing different extraction methods in L. esculentum, found lower values in seeds by electrical conductivity submitted by washing in running water and fermentation for 72 hours compared to immersion for 2 hours in $2.5 \% \mathrm{HCl}$ solution; without statistically significant difference between these methods and the methods of immersion in $10 \%$ commercial acetic acid solution and in $2.5 \%$ ammonium hydroxide solution for $2 \mathrm{~h}$. Thus, seed extraction methods should be assessed for their suitability to each species, because of their differences and influence on the physiological quality of the seeds.

\section{Final considerations}

The methods $M_{1}$ - friction in sieve under running water, without addition of $\mathrm{CaO}$; and $\mathrm{M}_{3}$ - fermentation for $24 \mathrm{~h}$, without addition of sucrose were found to be less favorable to the extraction of seeds of $\mathrm{H}$. undatus, as they favor decrease in GSI in seeds obtained from germination test and increase in MGT. In both tests where this variable was analyzed, contributing to the greater number of days 
necessary to the germination process, which jeopardizes the entire productive sector.

It should be emphasized that fermentation-based methods require more time to complete the seed extraction process. Thus, although methods $\mathrm{M}_{5}$ and $\mathrm{M}_{9}$ have proven to be more effective than the other methods, method $\mathrm{M}_{9}$ - immersion for $2 \mathrm{~h}$ in $10.0 \% \mathrm{HCl}$ solution was chosen, based on results obtained with analyzes of the variables, which implied shorter processing times. This has been a matter of concern for researchers since method $\mathrm{M}_{5}$ - fermentation for $48 \mathrm{~h}$ without addition of sucrose - uses fermentation. Therefore, it is only recommended when there is no need to reduce the pulping time or when $\mathrm{HCl}$ is not available. Carvalho and Nakagawa (2012) also highlighted the advantage of using acids to accelerate the extraction of seeds from flesh fruits.

\section{Materials and Methods}

\section{Characterization of the site and plant material}

The study was performed at the Seed Technology and Production Laboratory and Phytopathology Laboratory, at Londrina State University (UEL), Londrina-PR (Brazil). The seeds used were obtained from ripe fruits from mother plants of red pitaya with white pulp (Hylocereus undatus), approximately 10 years old, cultivated in an experimental area belonging to the UEL Agronomy Department, located at 2323' S and 511' $\mathrm{W}$ and average altitude of $560 \mathrm{~m}$.

Pitaya plants were grown in areas of soil classified as RED NITISOL Eutroferric latosol (EMBRAPA, 2013), with $2.0 \times 3.0$ $\mathrm{m}$ spacing and anchored on a 2.5-meter-high stake. According to Köppen classification, the climate of the region is Cfa type (humid subtropical climate).

\section{Methods of mucilage extraction}

In total, 19 fruits were collected; then, a spoon was used to get their pulp and seeds out, followed by maceration for 5 min. Due distribution type of the seeds in the pulp and their small size, which made it impossible to effectively separate the two components, the extraction methods of the mucilage used the mix of pulp and seeds.

The assessed methods were $M_{1}$ - friction for 3 min using a fine mesh sieve $(0.5 \mathrm{~mm})$ with running water; $\mathrm{M}_{2}-$ friction for 3 min using a fine mesh sieve $(0.5 \mathrm{~mm})$ with running water and addition of $\mathrm{CaO}$ (calcium oxide) (8:1 v:v, pulp:solution); $\mathrm{M}_{3}-$ fermentation for $24 \mathrm{~h}$ in distilled water (1:1.5 v:v, pulp:water); $M_{4}$ - fermentation for $24 \mathrm{~h}$ in distilled water and sucrose solution (10:1 m:m, water:sucrose and 1:1.5 v:v, pulp:solution); $\mathrm{M}_{5}-$ fermentation for $48 \mathrm{~h}$ in distilled water (1:1.5 v:v, pulp:water); $M_{6}$ - fermentation for $48 \mathrm{~h}$ in distilled water and sucrose solution (10:1 m:m, water:sucrose and 1:1.5 v:v, pulp:solution); $\mathrm{M}_{7}$ - immersion for $2 \mathrm{~h}$ in $\mathrm{HCl}$ solution (hydrochloric acid) at $2.5 \%\left(25 \mathrm{~mL} \mathrm{Kg}^{-1}\right.$ of pulp); $\mathrm{M}_{8}-$ immersion for $2 \mathrm{~h}$ in $5.0 \% \mathrm{HCl}$ solution ( $25 \mathrm{~mL} \mathrm{Kg}^{-1}$ of pulp) and $\mathrm{M}_{9}-$ immersion for $2 \mathrm{~h}$ in $10.0 \% \mathrm{HCl}$ solution $\left(25 \mathrm{~mL} \mathrm{Kg}^{-1}\right.$ of pulp).

After each methodology, the seeds were washed in running water with fine mesh sieve $(0.5 \mathrm{~mm})$ for $3 \mathrm{~min}$ (except for methods $M_{1}$ and $M_{2}$, which include this practice) and dried in the shade on paper towels at room temperature for 48 hours. Determination of seed moisture content was performed by the oven method at $105 \pm 3 \stackrel{\circ}{\circ}$ for $24 \mathrm{~h}$
(BRASIL, 2009), with two repetitions using $1 \mathrm{~g}$ of seeds. The treatments ranged from 9.18 to $10.27 \%$ moisture content.

\section{Experimental design and traits measured}

The experimental design was entirely randomized and the physiological quality of the seeds was assessed for the following tests:

Germination: four repetitions of 50 seeds were used for each extraction method, and the seeds were arranged in transparent polystyrene boxes with lids (Gerbox type), lined with blotting paper moistened with distilled water in the ratio of two and a half times the dry weight of the paper. The germination test was conducted in a germination chamber at $25 \stackrel{\circ}{ } \mathrm{C}$, under constant light, for 12 hours, when stabilization of the germination process was reached.

Accelerated aging: in this test, four subsamples of 50 seeds were used for each treatment. The seeds were distributed on a nylon screen fitted in transparent polystyrene boxes with lids (Gerbox type), in order to form a single layer, and $50 \mathrm{~mL}$ of distilled water was added to the bottom of each box. The experimental units were placed in a germination chamber at $41 \stackrel{\circ}{\circ}$ for $48 \mathrm{~h}$. After this period, the seeds were subjected to germination test under the same previously mentioned conditions.

The assessments of germination and accelerated aging tests were performed daily until stabilization of germination process. Seeds with root length equal to or greater than 2 $\mathrm{mm}$ were considered germinated, and the results were expressed in \% of germinated seeds. Also, the germination speed index (GSI) according to the methodology proposed by Maguire (1962), as well as the mean germination time (MGT), in days, according to Lima et al. (2006) were determined for each test.

The identification and quantification of plant pathogenic fungi detected in the seeds obtained from germination and accelerated aging tests were performed at the end of the experiment, after 11 days of incubation. The germinated seeds were not removed, and, thus, all the 50 seeds of each experimental unit were assessed. However, since the germinated seeds showed no microorganism structures, identification and quantification of plant pathogenic fungi were only performed in non-germinated seeds., i.e., few seeds were assessed. The seeds where mycelial growth was detected were removed and individually examined in stereoscopic microscope, and the fungi were identified through their reproductive structures. The results were expressed in percentage (\%) of each detected fungal species. Tetrazolium: the test was composed by two repetitions of 50 seeds for each extraction method. First, preconditioning of seeds was performed; they were arranged on blotting paper moistened with distilled water in the ratio of two and a half times the dry weight of the paper and packed in transparent polystyrene boxes with a lid (Gerbox ${ }^{\oplus}$ type). The experimental plots were arranged in a germination chamber at $25 \stackrel{\circ}{\circ}$, during $16 \mathrm{~h}$.

After this period, with the aid of a scalpel, the seeds were longitudinally sectioned along the embryo and $3 / 4$ of the endosperm, and then packed in transparent polystyrene boxes (Gerbox type), containing a blotting paper moistened with tetrazolium solution $(2,3,5$ triphenyl tetrazolium chloride) at the concentration of $1 \%$, in the ratio of two and a half times the dry weight of the paper. Subsequently, the material was placed in a germination chamber at $35 \stackrel{\circ}{ } \mathrm{C}$ for 3 $h$, for seed staining. 
Then, the seeds were washed in running water and kept submerged in water until they were individually examined with the aid of a magnifying glass with stand. Seed tissue of a bright red color was considered lively and vigorous, and the seed was classified as viable; if dark red and milky white stained, the tissue was considered deteriorated and dead, respectively, and seeds were not viable. The results were expressed in percentages of viable seeds (\%).

Electrical conductivity: the test involved four repetitions of 50 seeds per treatment. For each experimental unit, the seeds were placed in plastic containers to which $50 \mathrm{ml}$ of distilled and deionized water was added. Then the containers were incubated in a germination chamber at 25 oC, during 24 and $48 \mathrm{~h}$. After each period, the readings were performed with the aid of a digital conductivity meter Digimed model $\mathrm{CD}-21^{\circ}$, and the average values obtained were expressed in $\mu \mathrm{S} \mathrm{cm}^{-1}$.

\section{Statistical analysis}

The data was previously subjected to normality and homoscedasticity (homogeneity of variances) analyzes; for percentage germination data, transformation into arcsin $(x / 100)^{0.5}$ was performed to normalize the distribution. Later, the data was subjected to analysis of variance, and when a statistically significance difference was obtained, the averages were compared using the Scott-Knott test $(p<0.05)$.

\section{Conclusion}

The method of immersion for $2 \mathrm{~h}$ in $10.0 \% \mathrm{HCl}$ solution $\left(\mathrm{M}_{9}\right)$ has proven to be advantageous for the extraction of $H$. undatus seeds, as they allow the extraction of seeds with high physiological quality in short period.

\section{Acknowledgments}

The authors thank the financial support from CAPES (Coordination for the Improvement of Higher Education Personnel) and CNPq (National Council for Scientific and Technology Development) for granting the postgraduate scholarship and Fundação Araucária for the productivity scholarship.

\section{References}

Alves EU, Silva KB, Gonçalves EP, Cardoso EA, Alves AU (2009) Germinação e vigor de sementes de Talisia esculenta (St. Hil) Radlk em função de diferentes períodos de fermentação. Semin-Cienc Agrar. 30(4):761-770.

Anderson EF (2001) The Cactus family. 1st edn. Timber Press Portland, Oregon.

Andrade RA, Oliveira IVM, Silva MTH, Martins ABG (2008) Germinação de pitaya em diferentes substratos. Rev Caatinga. 21(1):71-75.
Bisognin DA, Menezes NL, Bellé RA, Albini AM (1997) Efeito do tamanho de fruto e do método de extração na qualidade fisiológica de sementes de porongo. Cienc Rural. 27(1):13-19.

Brasil. Ministério da Agricultura, Pecuária e Abastecimento (2009) Regras para análise de sementes. 1st edn. Mapa/ACS, Brasília.

Canto AR (1993) El cultivo de pitahaya en Yucatan. Universidad Autônoma Chapingo, Gobierno Del Estado de Yucatan.

Carvalho NM, Nakagawa J (2012) Sementes: Ciência, tecnologia e produção. 5th edn. Funep, Jaboticabal.

Cavariani C, Piana Z, Tillmann MAA, Minami K (1994) Métodos de remoção da mucilagem e qualidade fisiológica de sementes de tomate (Lycopersicon esculentum, Mill.). Sci Agric. 50(3):43-46.

Empresa Brasileira de Pesquisa Agropecuária - EMBRAPA (2013) Sistema brasileiro de classificação de solos. 3rd edn. Embrapa, Brasília.

Le Bellec F, Vaillant F, Imbert E (2006) Pitahaya (Hylocereus spp.): a new fruit crop, a market with a future. Fruits. 61(4):237-250.

Lima JD, Almeida CC, Dantas VAV, Siba BM, Moraes WS (2006) Efeito da temperatura e do substrato na germinação de sementes de Caesalpinia ferrea Mart. ex Tul. (Leguminosae, Caesalpinoideae). Rev Arvore. 30(4):513-518.

Lopes KP, Bruno RLA, Bruno GB, Azeredo GA (2001) Comportamento de sementes de romã (Punica granatum L.) submetidas à fermentação e secagem. Rev Bras Frutic. 23(2):369-372.

Maguire JD (1962) Speed of germination-aid in selection and evaluation for seedling emergence and vigor. Crop Sci. 2(1):176-177.

Marcos Filho J (2005) Fisiologia de sementes de plantas cultivadas. 1st ed. Piracicaba, Fealq.

Marin JLD, Gomes JA, Salgado JS (1987) Recomendação para a cultura do mamoeiro cv. Solo do Estado do Espírito Santo. 3rd edn. EMCAPA, Vitória.

Martins MR, Reis MC, Mendes Neto JA, Gusmão LL, Gomes JJA (2006) Influência de diferentes métodos de remoção do arilo na germinação de sementes de maracujazeiroamarelo (Passiflora edulis Sims f. flavicarpa Deg.). Rev FZVA. 13(2):28-38.

Mizrahi Y, Nerd A, Nobel PS (1997) Cacti as crops. Hortic Rev. 18:291-320.

Nerd A, Tel-Zur N, Mizrahi Y (2002) Fruit of vine and columnar cacti. In: Nobel PS (ed) Cacti: biology and uses. UCLA, Los Angeles.

Osipi EAF, Lima CB, Cossa CA (2011) Influência de métodos de remoção do arilo na qualidade fisiológica de sementes de Passiflora alata Curtis. Rev Bras Frutic. 33(1):680-685.

Sousa DMM, Bruno RLA, Andrade AP, Dornela CSM, Primo DMB (2009) Comportamento de sementes de palma (Opuntia ficus-indica I.) submetidas à fermentação e secagem. Rev Caatinga. 22(3):29-34.

Taylorson RB, Hendricks SB (1977) Dormancy in seeds. Annu Rev Plant Physiol. 28:331-354. 